\title{
STUDY OF FEEDING PRACTICES IN INFANTS ATTENDING PAEDIATRIC DEPARTMENT IN A TERTIARY CARE HOSPITAL
}

\author{
Sindhura Vinnakota ${ }^{1}$, Naveen Kumar Mallineni², Y. Asha ${ }^{3}$, P. Sandeep ${ }^{4}$
}

1Medical Officer, Special New Born Care Unit (SNCU), Department of Paediatrics, King George Hospital, Visakhapatnam, Andhra Pradesh, India.

${ }^{2}$ Civil Assistant Surgeon, Department of Plastic Surgery, Visakha Institute of Medical Sciences (VIMS), Visakhapatnam, Andhra Pradesh, India.

${ }^{3}$ Consultant Paediatrician, Department of Paediatrics, Amma Children Hospital, Ongole, Andhra Pradesh, India.

${ }^{4}$ Assistant Professor, Department of Paediatrics, RIMS, Srikakulam, Andhra Pradesh, India.

ABSTRACT
BACKGROUND
Optimum nutrition is essential for child survival and quality of survival. As per global public health recommendations, infants
should be exclusively breastfed for the first six months of life to achieve optimal growth, development and health. Thereafter, to
meet their evolving nutritional requirements, infants should receive nutritionally adequate and safe complementary foods while
breastfeeding continues for up to two years of age or beyond 4 . Infant feeding and rearing practices have a major effect on short
term and long-term nutritional status of infants. Present study is undertaken to assess the current feeding practices in infants
attending paediatrics department in a tertiary care hospital.

\section{METHODS}

Present study is a cross sectional study in which about 500 Mothers and their infants attending paediatric OPD, postnatal ward, paediatric ward of KGH for various reasons of health care, were selected for study. Statistical analysis was done using Epi Info 7.1.2.0 of Centre for Disease Control, USA and MedCalc 12.7.5 Belgium.

\section{RESULTS}

The median age of mothers in the study is 22 years in which about $54.4 \%$ were illiterate and $81 \%$ were house wives. Breast feeding suggestion during ANC to mothers by doctors is $79 \% .11 .2 \%$ children were given prelacteal feeds. Exclusive breast feeding was done by mothers in $88 \%$. When the mothers knowledge regarding the age of initiation of complimentary feeding is obtained, $2.2 \%$ of mothers thought complimentary feeding can be started when the child was between 2 to 3 months age, $9.8 \%$ felt that it can be started between 3 to 4 months of age; $15 \%$ felt $4-5$ months, about $23 \%$ felt 5 to 6 months, $29.4 \%$ felt 6 to 7 months, $21 \%$ felt that it can be started $>7$ months of age.

\section{CONCLUSIONS}

There is a need to improve health education regarding infant feeding practices like exclusive breast feeding and weaning. Problems during breast feeding should be taught during pregnancy. Counselling should be started antenatally to improve confidence in mothers and to identify problems like inverted nipple. Breast feeding and weaning are two major pillars in infant feeding which should be done appropriately to reduce infant morbidity and mortality.

HOW TO CITE THIS ARTICLE: Vinnakota S, Mallineni NK, Asha Y, et al. Study of feeding practices in infants attending paediatric department in a tertiary care hospital. J. Evolution Med. Dent. Sci. 2019;8(14):1135-1140, D0I: 10.14260/jemds/2019/252

\section{BACKGROUND}

Optimum nutrition is essential for child survival and quality of survival. Breast milk is the natural food for the infant and it is species specific. ${ }^{1}$ "The nature has designed the provision that infants be fed upon their mother's milk. They find their food and mother at the same time. It is complete nourishment for them, both for their body and soul."2

Breastfeeding is an unequalled way of providing ideal food for the healthy growth and development of infants; it is also an integral part of the reproductive process with important implications for the health of mother. ${ }^{3}$

'Financial or Other Competing Interest': None.

Submission 04-03-2019, Peer Review 25-03-2019,

Acceptance 28-03-2019, Published 08-04-2019.

Corresponding Author:

Dr. Naveen Kumar Mallineni,

Flat No. 102, ELRS Residency,

Beside Vaishnavi Hospital, Krishna Nagar,

Visakhapatnam-530002,

Andhra Pradesh, India.

E-mail:naveen.mallineni@gmail.com

DOI: $10.14260 /$ jemds $/ 2019 / 252$
As a global public health recommendation, infants should be exclusively breastfed for the first six months of life to achieve optimal growth, development and health. Thereafter, to meet their evolving nutritional requirements, infants should receive nutritionally adequate and safe complementary foods while breastfeeding continues for up to two years of age or beyond. 4

Infant feeding and rearing practices have a major effect on short term and long-term nutritional status of infants and vary from country to country and even place to place in a given country. In our country, breastfeeding has been the traditional way of feeding the newborn and is usually prolonged, leading to a delay in weaning and compromise of nutritional status of the infant. 5

Present study is undertaken to assess the current feeding practices in infants attending paediatrics department in a tertiary care hospital.

\section{Aims and Objectives}

1. To find out the prevailing feeding practices in infants attending tertiary care hospital. 
2. To identify the problems affecting infant feeding practices.

3. To analyze the factors that are influencing the mothers, families and Care givers in infant feeding.

4. To assess the knowledge regarding the feeding practices.

\section{METHODS}

\section{Study Design}

Present study is a cross sectional study.

\section{Study Period}

From October 2014 to July 2015 with a total period of 10 months.

\section{Study Setting}

Study was conducted at KGH Visakhapatnam.

\section{Study Population}

Mothers and their infants attending Paediatric OPD, postnatal ward, paediatric ward of KGH for various reasons of health care.

\section{Inclusion Criteria}

Mothers of infants from 0 to 1 year will be included.

\section{Exclusion Criteria}

Mothers with psychiatric illness.

\section{Sample Size}

500 Mothers.

\section{Methodology}

Informed consent is taken. Information about the knowledge and practices is collected through structured questions. Data are entered into a form designed for the purpose and converted into electronic database using ms excel.

\section{Statistical Analysis}

Statistical analysis was done using Epi info 7.1.2.0 of Centre for Disease Control, USA and MedCalc 12.7.5 Belgium.

\section{RESULTS}

The median age of the infants studied 118.5 days (95\% Cl: 83 to 142.4 days) with a range from 5 to 353 days.

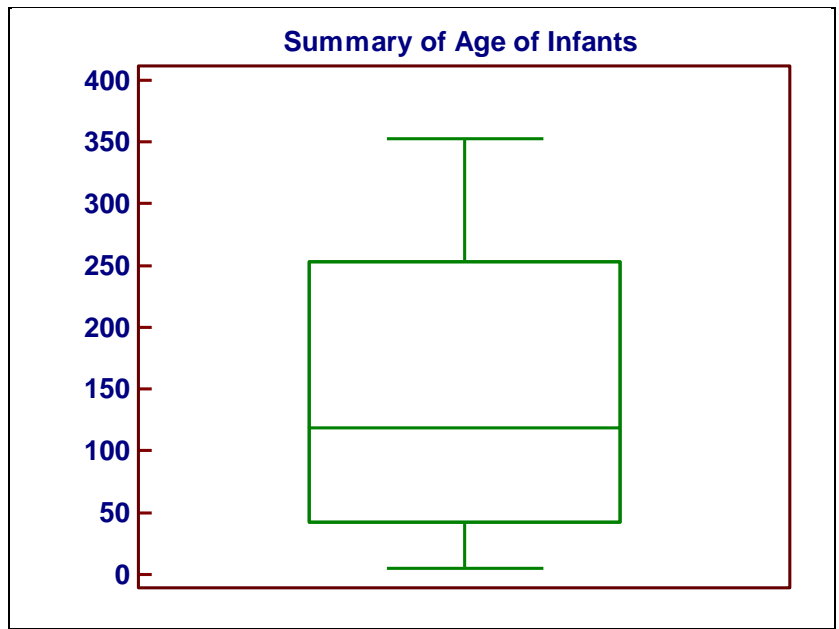

\section{Sex Distribution of Children}

Out of 500 infants studied $58.2 \%$ are females and $41.8 \%$ are males. The female children (95\% Cl: $53.73 \%$ to $62.54 \%$ ) are significantly more than the males $(95 \% \mathrm{Cl}: 37.46 \%$ to $46.27 \%)$.

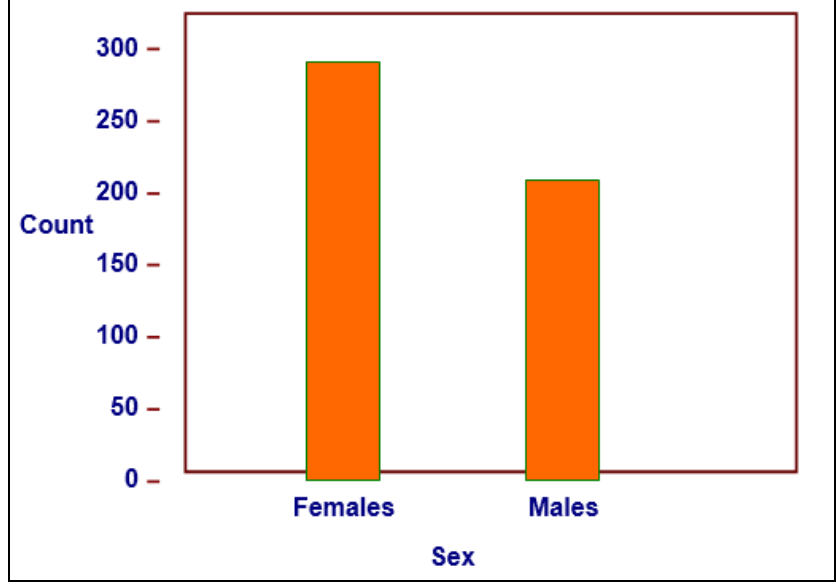

The median age of mothers in the study $(n=500)$ is 22 years (95\% Cl: 22 to 23 years). The mean age of mothers is $22.6 \pm 11.7$ years. The range is 16 years (youngest mothers) to 39 years (eldest mothers).

Significant proportion of mothers 54.4\% (95\% CL: 50\% to $59 \%$ ) are illiterates. Mothers with high school level education are $21 \%$ (95\% CL: $17.6 \%$ to $25 \%$ ).

Significant number of mothers' occupation is house wife $81 \%$ (95\% Cl: $77 \%$ to $84 \%$ ). Only $13 \%$ of the mothers are manual labourers and $6.2 \%$ are office work.

The mothers studied belong to Hindu, Muslim, Christian religions in a proportion of $72.4 \%, 22.8 \%, 4.8 \%$ respectively.

Most of the mothers $70.4 \%$ (95\% Cl: $66 \%$ to $74 \%$ ) belong to joint family and $29.6 \%$ ( $95 \% \mathrm{Cl}: 25 \%$ to $34 \%$ ) belong to nuclear families.

Out of 500 mothers only $24.8 \%$ ( $95 \% \mathrm{Cl}$ : $21 \%$ to $29 \%)$ mothers had more than 3 antenatal check-ups. The minimum number of 3 antenatal check-ups were taken by only $32 \%$ of mothers (95\% Cl: $27 \%$ to $36 \%$ ). $41.78 \%$ (95\% $\mathrm{Cl}: 37.41 \%$ to $46.29 \%$ ) of mothers received only 2 antenatal check-ups and $1.62 \%$ mothers received only one antenatal check-up.

During antenatal check-ups $71.2 \%$ (95\% Cl: $66.94 \%$ to $75.11 \%$ ) of mothers do not received suggestion for breast feeding during ANC. Whereas 28.8\% (95\% Cl: 24.9\% to 33\%) received suggestion during ANC.

Breast feeding suggestion during ANC to mothers by doctors is $79 \%$ (95\% Cl: $71.2 \%$ to $85.3 \%)$, in $16.2 \%$ of mothers (95\% Cl: $10.6 \%$ to $23.3 \%$ ) the breast-feeding suggestion was given by nurse, in $5 \%$ ( $95 \% \mathrm{Cl}$ : $2 \%$ to $10 \%$ ) given by ANM.

In $89 \%$ of children $(88.8 \%, 95 \% \mathrm{Cl}: 85.62 \%$ to $91.36 \%)$ prelacteal feeds were not given and $11.2 \%$ (95\% Cl: $8.64 \%$ to $14.38 \%$ ) children were given prelacteal feeds.

Out of 56 babies who received prelacteal feeds $44.64 \%$ (95\% Cl: $31.34 \%$ to $58.53 \%$ ) received sugar water, $25 \%$ ( $95 \% \mathrm{Cl}: 14.39 \%$ to $38.37 \%$ ) received top fed milk, $19.64 \%$ (95\% Cl: $10.23 \%$ to $32.43 \%$ ) received honey and $10.7 \%$ (95\% $\mathrm{Cl}: 4.03 \%$ to $21.88 \%$ ) received glucose water.

In $39.4 \%$ of children $(95 \% \mathrm{Cl}-35.12 \%$ to $43.85 \%)$ initiated breast feeding within one hour. $36.2 \%$ of children $(95 \% \mathrm{Cl}-32.01 \%$ to $40.60 \%)$ initiated breast feeding in $1-4$ 
hours after delivery. $12.6 \%(95 \% \mathrm{Cl}-9.88 \%$ to $15.91 \%)$ children received breast milk 24 hours after delivery.

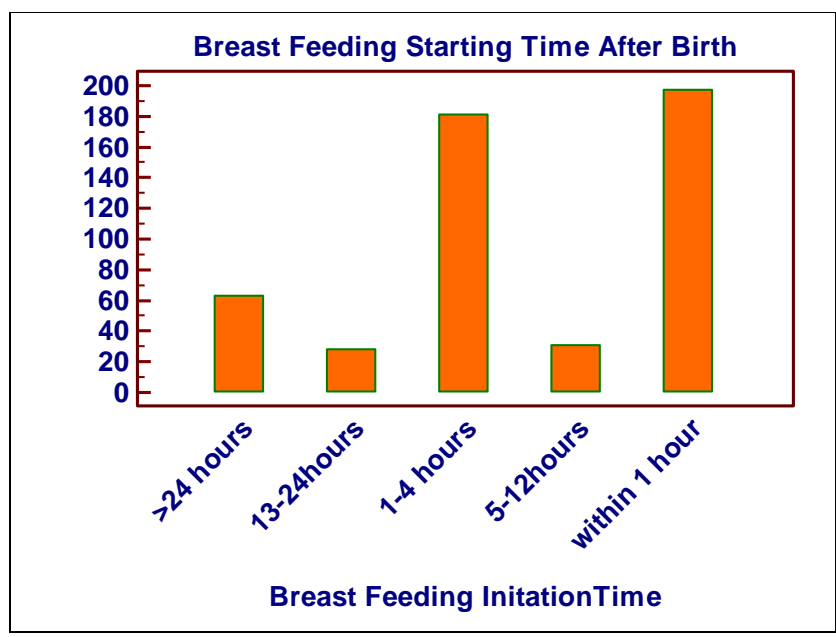

Among 500 mothers studied 454 mothers fed colostrum to their children, $91 \%(95 \% \mathrm{Cl}-87.83 \%$ to $93.12 \%)$ In comparison to only $9.2 \%$ of mothers $(95 \% \mathrm{Cl}-6.88 \%$ to $12.17 \%$ ) who did not fed colostrum to babies.

Out of 46 mothers who did not feed their babies with colostrum most of them $56.5 \%$ (95\% Cl: $41.1 \%$ to $71 \%$ ) did not feed colostrum as they were advised by grandmothers, due to custom \&tradition $24 \%$ (95\% Cl: $12.59 \%$ to $38.77 \%$ ) and about $20 \%(95 \% \mathrm{Cl}: 9.36 \%$ to $33.9 \%$ ) thinking that colostrum is not suitable for baby health.

Exclusive breast feeding was done by mothers in $88 \%$ (95\% Cl: $85 \%$ to $91 \%$ ) of children. In $6.4 \%$ children $(95 \% \mathrm{Cl}$ $4.49 \%$ to $9 \%$ ) predominant breast feeding. In $5.6 \%$ (95\% Cl: $3.8 \%$ to $8 \%$ ) partial breast feeding was implemented. Over all $12 \%$ children are not getting the benefit of exclusive breast feeding.

\section{Graph Showing Breast Feeding Type}

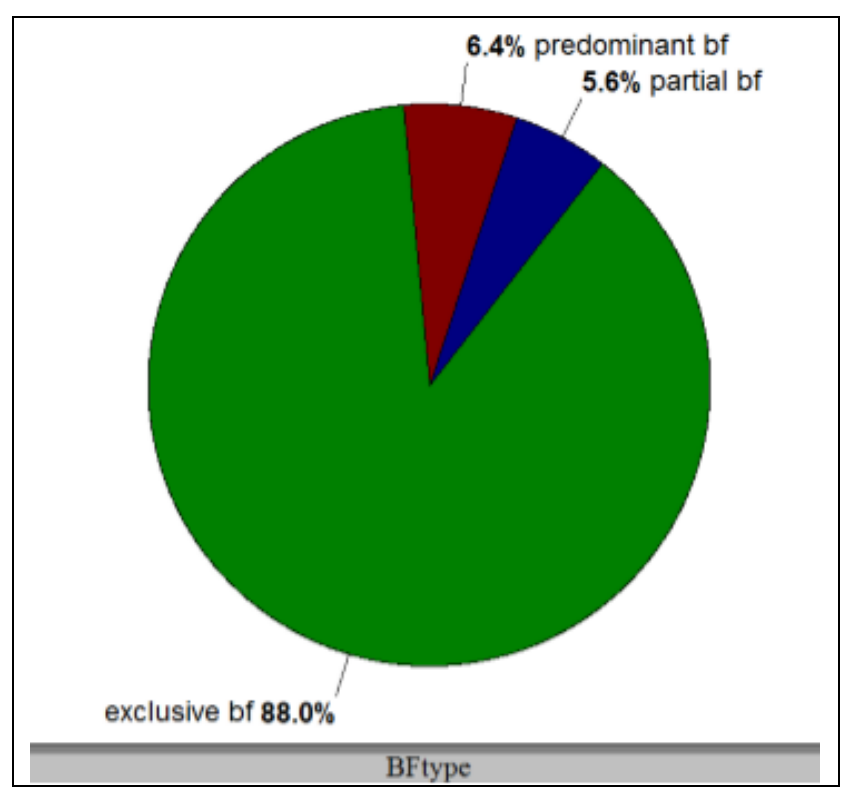

\begin{tabular}{|c|c|c|c|c|}
\hline $\begin{array}{c}\text { Exclusive Breast- } \\
\text { Feeding } \\
\text { Knowledge } \\
\end{array}$ & Frequency & Percent & $\begin{array}{r}95 \\
\text { Confi } \\
\text { Lin } \\
\end{array}$ & $\begin{array}{l}\% \\
\text { dence } \\
\text { its }\end{array}$ \\
\hline 1 Month & 5 & $1.14 \%$ & $0.42 \%$ & $2.79 \%$ \\
\hline 2 Months & 3 & $0.68 \%$ & $0.18 \%$ & $2.15 \%$ \\
\hline 3 Months & 15 & $3.41 \%$ & $1.99 \%$ & $5.69 \%$ \\
\hline 4 Months & 135 & $30.68 \%$ & $26.45 \%$ & $35.26 \%$ \\
\hline 5 Months & 70 & $15.91 \%$ & $12.69 \%$ & $19.74 \%$ \\
\hline 6 Months & 156 & $35.45 \%$ & $31.02 \%$ & $40.15 \%$ \\
\hline$>6$ Months & 56 & $12.73 \%$ & $9.83 \%$ & $16.29 \%$ \\
\hline Total & 440 & $100.00 \%$ & & \\
\hline
\end{tabular}

Out of 440 mothers who gave exclusive breast feeding of some duration $35.5 \%$ (95\% Cl: $31 \%$ to $40 \%$ ) of mothers have correct knowledge of exclusive breast feeding. Among the rest of mothers $16 \%$ ( $95 \% \mathrm{Cl}: 12.69 \%$ to $19.7 \%$ ) think exclusive breast feeding is of 5 months. $31 \%$ (95\% Cl: $26.45 \%$ to $35.2 \%$ ) think exclusive breast feeding of 4 months duration. $3.4 \%(95 \% \mathrm{Cl}: 2 \%$ to $5.7 \%)$ think it is 3 months duration. $0.7 \%$ ( $95 \% \mathrm{Cl}: 0.18 \%$ to $2.1 \%$ ) think it is 2 months duration. Approximately $13 \%$ (95\% Cl: $9.8 \%$ to $16.3 \%)$ mothers felt exclusive breast feeding is of $>6$ months duration.

Out of 500 mothers when information was sought about duration of each breast feeding session most of mothers 72.2 \% (95\% Cl: $68 \%$ to $76 \%$ ) breastfed their babies for $5-10$ minutes, $19 \%$ (95\% Cl: $15.7 \%$ to $22.7 \%$ ) for $10-15$ minutes, 5.6\% (95\% Cl: $3.8 \%$ to $8 \%$ ) for < 5 minutes, $3.2 \%(95 \% \mathrm{Cl}$ $2 \%$ to $5.2 \%$ ) for $15-20$ minutes.

\begin{tabular}{|c|c|c|c|c|}
\hline $\begin{array}{c}\text { Pattern of } \\
\text { Breast } \\
\text { Feeding }\end{array}$ & Frequency & Percent & \multicolumn{2}{|c|}{$\begin{array}{c}\text { 95\% Confidence } \\
\text { Limits }\end{array}$} \\
\hline Clockwise & 8 & $1.60 \%$ & $0.75 \%$ & $3.26 \%$ \\
\hline $\begin{array}{c}\text { Demand } \\
\text { Feeding }\end{array}$ & 492 & $98.40 \%$ & $96.74 \%$ & $99.25 \%$ \\
\hline Total & $\mathbf{5 0 0}$ & $\mathbf{1 0 0 . 0 0 \%}$ & & \\
\hline \multicolumn{4}{|c}{ Practice of Breast-Feeding Pattern } \\
\hline
\end{tabular}

As regards to exclusive breast-feeding patterns most of the mothers (98.4\%, 95\% Cl: $96.74 \%$ to $99.25 \%$ ) are giving demand feeding. Only $1.6 \%$ followed a time schedule.

Regarding the lactation promotion method 58.4\%(95\% $\mathrm{Cl}$ : $53.93 \%$ to $62.74 \%$ ) mothers have chosen diet as a method of promoting breast milk production, more frequent breast feeding is opted by $25 \%(95 \% \mathrm{Cl}: 21.31 \%$ to $29 \%$ ) of mothers, $11.2 \%$ (95\% Cl: $8.64 \%$ to $14.38 \%$ ) felt that minimal physical activity (rest) will promotes and $5.4 \%$ felt that some medicine will promote lactation.

$45 \%$ (95\% Cl - 40.6 to $49.48 \%$ ) of mothers felt that vegetarian diet promotes lactation, about $42 \%(95 \% \mathrm{Cl}$ 37.26 to $46 \%$ ) do not feel that any particular diet is needed for lactation promotion. $13.4 \%(95 \% \mathrm{Cl}-10.6$ to $16.78 \%)$ prefer non vegetarian diet

Out of 500 mothers $76.4 \%$ (95\% Cl $-72.3 \%$ to $27.6 \%$ ) feel that breast feeding can be continued during maternal illness. Whereas $23 \%$ (95\% Cl $-20 \%$ to $27.6 \%$ ) think that breast feeding should not be given during maternal illness.

Among the mothers studied $91 \%$ (95\% Cl $-87.6 \%$ to 93\%) feel that breast feeding can be continued even during baby's illness. In $9.4 \%(95 \% \mathrm{Cl}-7 \%$ to $12.4 \%)$ think that breastfeeding should not be given during baby's illness. 
Out of 31 mothers who started top feeds $64.5 \%(95 \% \mathrm{Cl}$ $45.3 \%$ to $81 \%$ ) mothers gave top feds due to insufficient mother's milk, in about $13 \%(95 \% \mathrm{Cl}-3.6 \%$ to $30 \%)$ mothers are working, in $9.7 \%(95 \% \mathrm{Cl}-2 \%$ to $25 \%)$ due to advise given by grandmothers, in $6.45 \%(95 \% \mathrm{Cl}-0.8 \%$ to $21 \%)$ it is due to maternal illness and in another $6.45 \%$ it is due to subsequent pregnancy.

In group of mothers who gave top feed $61.3 \%(95 \% \mathrm{Cl}$ : $42 \%$ to $78 \%$ ) gave buffalo milk, about $26 \%$ (95\% Cl: $11.8 \%$ to $44 \%$ ) formula feeds, $9.7 \%$ (95\% Cl: $2 \%$ to $25 \%$ ) cow's milk and $3.2 \%$ (95\% Cl: $0.08 \%$ to $16 \%$ ) goats milk.

Top feeding method are by bottle in 74\% (95\% Cl: 55\% to $88 \%$ ), by Paladai $22.6 \%$ ( $95 \% \mathrm{Cl}: 9.5 \%$ to $41 \%$ ) and in $3.23 \%$ (95\% Cl: $0.08 \%$ to $16 \%$ ) with spoon.

When the mothers knowledge regarding the age of initiation of complimentary feeding is obtained 2.2\% (95\% $\mathrm{Cl}: 1.1 \%$ to $4 \%$ ) of mothers thought complimentary feeding has to be started between 2 to 3 months age of the child $9.8 \%$ (95\% Cl: $7.4 \%$ to $12.8 \%$ ) felt it between 3 to 4 months, $15 \%$ (95\% Cl: $12 \%$ to $18 \%$ ) felt at $4-5$ months, about $23 \%$ (95\% Cl: $19 \%$ to $26.5 \%$ ) felt it between 5 to 6 months, in $29.4 \%$ (95\% Cl: $25.4 \%$ to $33.6 \%$ ) it is 6 to 7 months, $>7$ months it is $21 \%$ (95\% Cl: $17.5 \%$ to $25 \%$ )

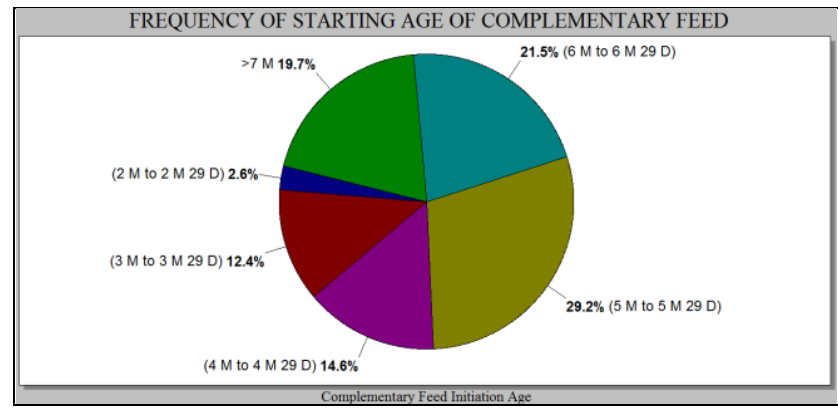

Complimentary feeding pattern in $68.2 \%$ (95\% $\mathrm{Cl}: 62 \%$ to $74 \%$ ) is time wise schedule and in about $32 \%$ (95\% Cl: $26 \%$ to $38 \%$ ) as per the demand of the child.

The type of complimentary feed initially started could be evaluated in 233 children. In $46 \%$ (95\% Cl: $39 \%$ to $52 \%$ ) it is rice dhal in $40.34 \%$ ( $95 \% \mathrm{Cl}: 34 \%$ to $47 \%$ ) it is Cerelac. In about $7 \%$ (95\% Cl: $4 \%$ to $11 \%$ ) other homemade diet, in $4.7 \%(95 \% \mathrm{Cl}: 3 \%$ to $8 \%)$ it is biscuits and in $2.2 \%(95 \% \mathrm{Cl}$ : $0.7 \%$ to $5 \%$ ) it is fruit juice.

In 46 babies complimentary feed introduced after 7 months of age, out of which $61 \%$ (95\% Cl: $45 \%$ to $75 \%$ ) delayed as the mother felt that breast milk was sufficient for the baby and In $39.1 \%$ (95\% Cl: $25 \%$ to $54.6 \%$ ) the delay in complimentary feed is due to opinion of the mother that complimentary feed may cause diarrhoea or not digestible to the baby.

\section{DISCUSSION}

\begin{tabular}{|c|c|c|c|c|c|c|c|c|c|}
\hline & & $\begin{array}{c}\text { Present } \\
\text { Study } \\
\text { 2014-15 }\end{array}$ & $\begin{array}{c}\text { Syed E } \\
\text { Mahmood } \\
2012^{6}\end{array}$ & \begin{tabular}{|c|} 
Abhay \\
Shivaram \\
Bagul 20117 $^{7}$
\end{tabular} & $\begin{array}{c}\text { Maheswari } \\
\text { Ekambaram } \\
2010^{8}\end{array}$ & $\begin{array}{c}\text { Sima Roy, } \\
2009^{9}\end{array}$ & $\begin{array}{c}\text { Apurupa } \\
\text { Sinhababu } \\
2008^{10}\end{array}$ & $\left|\begin{array}{c}\text { Nitin } \\
\text { Joseph } \\
2004^{11}\end{array}\right|$ & $\begin{array}{l}\text { Arun } \\
\text { Gupta, } \\
2003^{12}\end{array}$ \\
\hline Number & & 500 & 123 & 384 & $\begin{array}{c}100 \\
\text { (Postnatal } \\
\text { Mothers) }\end{array}$ & \begin{tabular}{|c}
120 \\
$(6$ Months-2 \\
yrs.)
\end{tabular} & 324 & 194 & \begin{tabular}{|c|}
8953 \\
$(0-9$ \\
Months $)$
\end{tabular} \\
\hline Baby Age & & \begin{tabular}{|c|} 
Median Age 118.5 \\
Days \\
(95\% Cl- 83 to \\
$142.4)$ \\
\end{tabular} & - & - & - & - & - & - & - \\
\hline Baby Sex & $\begin{array}{l}\mathrm{M} \\
\mathrm{F}\end{array}$ & $\begin{array}{l}41.8 \% \\
58.2 \% \\
\end{array}$ & - & - & - & - & $\begin{array}{l}46.6 \% \\
53.4 \% \\
\end{array}$ & - & $\begin{array}{l}54.6 \% \\
45.4 \% \\
\end{array}$ \\
\hline Mother Age & & $\begin{array}{c}\text { Median: } 22 \text { ( } 95 \% \mathrm{Cl}- \\
22 \text { to } 23 \text { Years) } \\
<20 \text { Yrs.- } 18 \% \\
20 \text { to } 29-79.4 \% \\
>30-2.6 \%\end{array}$ & $\begin{array}{c}18 \text { to } 23- \\
39.8 \% \\
24 \text { to } 29- \\
38.3 \% \\
>30-21.9 \%\end{array}$ & - & $\begin{array}{c}18 \text { to } 35 \\
\text { Average- } 25.18 \text { Years } \\
\pm 3.81 \text { Years }\end{array}$ & - & - & & \begin{tabular}{|c} 
Up to $20-$ \\
$17.7 \%$ \\
21 to $25-$ \\
$44.8 \%$ \\
$>25-37.5 \%$
\end{tabular} \\
\hline Mother Education & $\begin{array}{l}\text { Illiterate } \\
\text { Literate }\end{array}$ & $\begin{array}{l}54.4 \% \\
45.6 \%\end{array}$ & $\begin{array}{l}69.9 \% \\
30.1 \%\end{array}$ & $\begin{array}{l}19.73 \% \\
80.27 \%\end{array}$ & $\begin{array}{l}15 \% \\
75 \%\end{array}$ & $\begin{array}{l}18.4 \% \\
81.6 \%\end{array}$ & - & - & $\begin{array}{l}30.4 \% \\
69.6 \%\end{array}$ \\
\hline Occupation & $\begin{array}{c}\text { Housewife } \\
\text { Working }\end{array}$ & $\begin{array}{l}80.8 \% \\
19.2 \% \\
\end{array}$ & $\begin{array}{c}99.1 \% \\
0.9 \% \\
\end{array}$ & $\begin{array}{l}28.94 \% \\
71.06 \% \\
\end{array}$ & $\begin{array}{l}67 \% \\
33 \% \\
\end{array}$ & $\begin{array}{l}69.1 \% \\
30.9 \% \\
\end{array}$ & - & & $\begin{array}{l}81.7 \% \\
18.3 \% \\
\end{array}$ \\
\hline Type of Family & $\begin{array}{l}\text { Joint } \\
\text { Nuclear }\end{array}$ & $\begin{array}{l}70.4 \% \\
29.6 \%\end{array}$ & $\begin{array}{l}46.6 \% \\
54.4 \%\end{array}$ & - & $\begin{array}{l}53 \% \\
47 \%\end{array}$ & $\begin{array}{l}34.1 \% \\
65.9 \%\end{array}$ & - & - & - \\
\hline ANC & $\begin{array}{l}\text { Yes } \\
\text { No }\end{array}$ & $\begin{array}{c}98.6 \% \\
1.4 \%\end{array}$ & - & - & $\begin{array}{c}97 \% \\
3 \%\end{array}$ & - & - & - & - \\
\hline ANC Provider & $\begin{array}{c}\text { Doctor } \\
\text { ANM } \\
\text { TBA } \\
\text { others }\end{array}$ & $\begin{array}{l}95.54 \% \\
3.45 \% \\
0.41 \% \\
0.61 \%\end{array}$ & - & - & - & - & - & - & - \\
\hline ANC Place & $\begin{array}{c}\text { Home } \\
\text { PHC/CHC } \\
\text { Govt. Hosp } \\
\text { Clinic } \\
\text { Pvt. Hosp }\end{array}$ & $\begin{array}{c}1.01 \% \\
9.33 \% \\
36.92 \% \\
8.52 \% \\
44.22 \%\end{array}$ & - & - & - & - & - & - & - \\
\hline NO. of ANC & $\begin{array}{c}<3 \\
3 \text { or Above }\end{array}$ & $\begin{array}{l}43.4 \% \\
56.6 \%\end{array}$ & $\begin{array}{l}75.6 \% \\
24.4 \%\end{array}$ & - & - & - & - & - & - \\
\hline
\end{tabular}




\begin{tabular}{|c|c|c|c|c|c|c|c|c|c|}
\hline BF Suggestion During ANC & $\begin{array}{l}\text { Yes } \\
\text { No }\end{array}$ & $\begin{array}{l}28.8 \% \\
71.2 \%\end{array}$ & $\begin{array}{l}30.1 \% \\
69.9 \%\end{array}$ & - & $\begin{array}{l}17 \% \\
83 \%\end{array}$ & - & - & - & - \\
\hline BF Suggestion by Whom & $\begin{array}{c}\text { ANM } \\
\text { Nurse } \\
\text { Doctor }\end{array}$ & $\begin{array}{c}4.93 \% \\
16.2 \% \\
78.87 \%\end{array}$ & - & - & - & - & - & - & - \\
\hline Birth Place & $\begin{array}{l}\text { Home } \\
\text { Hospital }\end{array}$ & $\begin{array}{r}5.8 \% \\
94.2 \%\end{array}$ & $\begin{array}{l}49.6 \% \\
51.4 \%\end{array}$ & $\begin{array}{l}17.1 \% \\
82.9 \%\end{array}$ & - & $\begin{array}{l}6.67 \% \\
93.3 \%\end{array}$ & - & $25 \%$ & - \\
\hline Prelacteal & & $\begin{array}{l}11.2 \% \\
88.8 \% \\
\end{array}$ & $\begin{array}{l}22.76 \% \\
77.24 \% \\
\end{array}$ & $\begin{array}{l}78.61 \% \\
21.39 \% \\
\end{array}$ & & $\begin{array}{l}29.16 \% \\
70.84 \% \\
\end{array}$ & $\begin{array}{l}27.4 \% \\
72.6 \% \\
\end{array}$ & $\begin{array}{l}33.5 \% \\
66.5 \% \\
\end{array}$ & $\begin{array}{l}49.2 \% \\
50.8 \% \\
\end{array}$ \\
\hline Type of Prelacteal & Sugar Water & $44.64 \%$ & - & - & ـ & - & ـ & $63.1 \%$ & $20 \%$ \\
\hline BF Initiation & $\begin{array}{c}<1 \mathrm{Hr} . \\
1-24 \mathrm{Hrs} . \\
>24 \mathrm{Hrs} .\end{array}$ & $\begin{array}{c}39.4 \% \\
48 \% \\
12.6 \% \\
\end{array}$ & $\begin{array}{l}22 \% \\
57 \% \\
21 \% \\
\end{array}$ & $\begin{array}{c}32.56 \% \\
61.85 \% \\
5.59 \%\end{array}$ & - & $\begin{array}{c}16.67 \% \\
60 \% \\
23.33 \% \\
\end{array}$ & - & - & $28 \%$ \\
\hline Colostrum & $\begin{array}{l}\text { Yes } \\
\text { No }\end{array}$ & $\begin{array}{l}90.8 \% \\
9.2 \%\end{array}$ & $84.6 \% 15.4 \%$ & $\begin{array}{l}21.38 \% \\
78.61 \%\end{array}$ & - & $\begin{array}{l}90 \% \\
10 \%\end{array}$ & - & - & - \\
\hline $\begin{array}{l}\text { Colostrum } \\
\text { Not Given }\end{array}$ & $\begin{array}{l}\text { Not Good for } \\
\text { Baby }\end{array}$ & $19.57 \%$ & $52.7 \%$ & - & - & - & - & - & - \\
\hline BF Type & $\begin{array}{c}\text { Exclusive } \\
\text { BF } \\
\text { Predominant } \\
\text { Partial BF }\end{array}$ & $\begin{array}{l}88 \% \\
6.4 \% \\
4.6 \%\end{array}$ & $77.24 \%$ & - & - & - & - & - & $\begin{array}{c}39.68 \% \\
11.3 \% \\
49.02 \%\end{array}$ \\
\hline $\begin{array}{c}\text { EBF Up To } \\
6 \text { Months Knowledge }\end{array}$ & - & $35.45 \%$ & - & - & $38 \%$ & - & - & - & - \\
\hline $\begin{array}{c}\text { EBF up to } 4 \text { to } 6 \\
\text { Months Actual Duration }\end{array}$ & - & $69.3 \%$ & - & $36.84 \%$ & - & $28.33 \%$ & - & $41.7 \%$ & $39.7 \%$ \\
\hline BF Pattern & $\begin{array}{l}\text { Demand } \\
\text { Clockwise }\end{array}$ & $\begin{array}{c}98.4 \% \\
1.6 \%\end{array}$ & & - & - & - & - & $\begin{array}{l}87.1 \% \\
12.9 \%\end{array}$ & - \\
\hline $\begin{array}{l}\text { Complimentary Feeding } \\
\text { Age of Initiation }\end{array}$ & $\begin{array}{l}<6 \text { Months } \\
>6 \text { Months }\end{array}$ & $\begin{array}{l}58.8 \% \\
41.2 \% \\
\end{array}$ & $24.4 \%$ & - & - & $71.66 \%$ & - & - & $70 \%$ \\
\hline $\begin{array}{c}\text { BF During Illness of } \\
\text { Mother }\end{array}$ & $\begin{array}{l}\text { Yes } \\
\text { No }\end{array}$ & $76.4 \%$ & & - & $50 \%$ & - & - & - & - \\
\hline \multicolumn{10}{|c|}{ Comparison of Studies } \\
\hline
\end{tabular}

Comparison with other studies done.

The median age of mothers is 22 years ( $95 \% \mathrm{Cl}: 22$ to 23 years). In Maheswari Ekambaram's study the average age of the mothers is $25.18 \pm 3.81$ years. In our study most of the mothers belong to 20 to 29 years. In Syed Mahmood's study young mothers less than 20 years are also high in number. In our study young mothers less than 20 years are $18 \%$ which is very similar to Arun Gupta study (17.7\%).

Illiterate mothers in our study are 54.4\% (95\% Cl: 49.92 to $58.81 \%$ ). In Arun Gupta's study the sample of mothers' representative of 25 different states in India. In their study the illiterate mothers are $30.4 \%$ and, in our study, illiterate mothers are $54.4 \%$. It indicates that maternal illiteracy in our population is greater than average maternal illiteracy in India. In Syed Mahmood's study illiterate mothers are high (70\%).

Most of the mothers in our study are house wives (80.8\%, $95 \% \mathrm{Cl}: 77 \%$ to $84 \%$ ). The proportion of house wives in our study, Arun Gupta's study, Maheswari Ekambaram's study and Sima Roy's study are more or less similar. In syed Mahmood's study the proportion of house wives is very high. In Abhay Shivaram Bagulu's study the proportion of house wives is very low.

The median age of infants in our study is around 4 months (95\% Cl: 83 to 142.4 days, range from 5 days to 12 months). In our study female children are significantly more
(58.2\%, 95\% Cl: $53.73 \%$ to $62.54 \%)$. In Apurba Sinha babu's study also females are more. But in Arun Gupta's study males are preponderant.

In our study joint families are significantly more $(70.4 \%$, $95 \% \mathrm{Cl}: 66.2$ to $74.3 \%)$ than nuclear families $(29.6 \%, 95 \% \mathrm{Cl}$ : $25.67 \%$ to $33.85 \%$ ). In Syed Mohmood's study, Maheswari Ekambaram's study and Sima Roy's study (46.6\%, 53\% and $34.1 \%$ respectively) joint family proportion is low. Where ever joint family system is common, the chances for promotion of breast feeding will be better. In Arun Gupta's study the proportion of exclusive breast feeding is $39.68 \%$ and in Syed Mohmood's study it is $77.2 \%$.

Mothers who received antenatal checkups in our study are $88.6 \%$ (95\% Cl: 97 to $99.4 \%$ ). In our study antenatal checkups of 3 and above are of $56.6 \%$ which is higher than that found in Syed Mohmood's study (24.4\%). Most of the mothers in our study received antenatal checkups by a doctor (95\% Cl: 93.2 to $97.1 \%$ ). This indicates a positive trend in the society where-in the pregnant women are receiving better antenatal checkups more often by qualified and trained healthcare personnel. Significant proportions of pregnant women are receiving antenatal checkups in a hospital setting higher than primary care facility. But there is no significant difference between government and private hospitals.

In our study and others' studies (Syed Mohmood and Maheswari Ekambaram study) the mothers who received 
breast feeding suggestion during antenatal checkups is low. In our study the proportion of mothers who delivered in hospital are high (94.2\%), similar to others' observations (82.9\% in Abhay Shivaram's study and 93.33\% in Sima Roy's study), but in Syed Mohmood's study (51.4\%) proportion is low.

The proportion of mothers who gave prelacteal feeds is low in our study when compared to other studies.

The optimum initiation time of breast feeding is less than 1 hour after birth. Though this proportion is less in our study and needs improvement by health education, is still better than the observations by others. In other studies, the initiation of breast feeding in less than 1 hour after birth is $16.67 \%$ (in Sima Roy's Study) and $32.5 \%$ (in Abhay Shivaram's Study).

In our study most of the mothers fed colostrum to their babies (91\%, 95\% Cl: $87.8 \%$ to $93.1 \%$ ). Our observations are similar to that of Sima Roy's (90\%) and Syed Mohmood's study (84.6\%). In Shivaram's study the colostrum feeding proportion is very low

In Syed Mohmood's study exclusive breast-feeding proportion is $77.24 \%$ and in Arun Gupta's study 39.68\%. Exclusive breast-feeding proportion up to 6 months in our study is $24.75 \%$ which needs improvement by optimum health education strategies. Exclusive breast-feeding duration up to 4 to 6 months in our study is $69.3 \%$. But there is a drop in the proportion of mothers who exclusively breasted their children up to 6 months (25.75\%).

Most of the mothers in our study (98.4\%) breast fed their children on demand which is similar to the observation by Nithin Joseph's (87.1\%)

In our study $76.4 \%$ of mothers have the knowledge that breast feeding can be continued during maternal illness. In Maheswari Ekambaram's study 50\% of mothers have such knowledge. In our study $15.6 \%$ of the mothers have the incorrect knowledge that breast milk secretion can be promoted by rest and medications. Though the proportion of mothers who think lactation can be promoted by medication and rest is small, can still be further educated correctly. In our study $58.4 \%$ of mothers prefer either vegetarian or nonvegetarian diet for lactation promotion which is indicative of inappropriate knowledge.

In our study significant number of mothers did not give any top feed during the period of exclusive breast feeding. The proportion of mothers who gave top feeds is very small $(6.2 \%, 95 \% \mathrm{Cl}: 4.3 \%$ to $8.78 \%)$ in our observation.

In our observation nearly $60 \%$ of mothers introduced complimentary feeding below 6 months age of the children. In Syed Mohmood's study the proportion is smaller (24.4\%). This may be due to the mothers feeling inappropriately that complimentary feeds are required below 6 months. This needs to be corrected by proper health education.

Only $29.4 \%$ of mothers (95\% Cl: $25.4 \%$ to $33.6 \%$ ) are having correct knowledge regarding age of starting of complementary feeds. About $49.6 \%$ mothers think that complementary feeding has to be started before 6 months of the age of the child. About $21 \%$ of mothers think complementary feeding has to be started from 7 months and above. This indicates that overall $70.6 \%$ of mothers are having incorrect knowledge regarding age of initiation of complementary feeding and this aspect needs proper health education strategies.
Nearly $45 \%$ of the mothers are giving inappropriate complementary feed (Biscuits and Cerelac) to their children. From the nutritional and financial point of view this needs to be corrected by appropriate health education.

Significant proportion of mothers $(68.24 \%, 95 \% \mathrm{Cl}$ : $61.84 \%$ to $74.17 \%$ ) are following clockwise timetable pattern while giving complementary feeds instead of the desirable biological clock method (demand feeding).

Nearly $20 \%$ of mothers delayed the initiation of complementary feeding. Out of them nearly $61 \%$ mothers feel that breast feeding is still adequate, and 39\% mothers feel that complementary feeding is not digestible. This also needs correction by proper health education.

\section{CONCLUSIONS}

There is a need to improve health education regarding infant feeding practices like exclusive breast feeding and weaning. Expecting mothers should be taught about problems during breast feeding during pregnancy. Counselling should be started antenatally to improve confidence in mothers and to find out problems like inverted nipple. Breast feeding and weaning are two major pillars in infant feeding which should be done appropriately to reduce infant morbidity and mortality.

\section{REFERENCES}

[1] Elizabeth KE. Nutrition and Child Development. $4^{\text {th }}$ edn. Paras Medical Publisher 2010: p. 1-63.

[2] Singh M. Care of the newborn. $7^{\text {th }}$ edn. CBS Publication 2014: p. 168-71.

[3] WHO: Infant and young child nutrition. Global strategy for infant and young child feeding, Executive board, 109th session report 2001: p. 1-20.

[4] WHO: Global strategy for infant and young child feeding. 2003: p. 1-30.

[5] Singhania RU, Kabra SK, Bansal A. Infant feeding practices in educated mothers from upper socioeconomic status. Indian Paediatrics 1990;27(6):591-3.

[6] Mahmood SE, Srivastava A, Shrotriya VP, et al. Infant feeding practices in the rural population of north India. Journal of Family and Community Medicine 2012;19(2):130-5.

[7] Bagul AS, Supare MS. The infant feeding practices in an urban slum of Nagpur, India. Journal of Clinical Diagnostic and Research 2012;6(9):1525-7.

[8] Ekambaram M, Bhat VB, Ahamed MSP. Knowledge, attitude and practice of breastfeeding among postnatal mothers. 2010-07 - 2010-12;14:2.

[9] Roy S, Dasgupta A, Pal B, et al. Feeding practices of children in an urban slum of Kolkata. Indian J Community Med 2009;34(4):362-3.

[10] Sinhababu A, Mukhopadhyay DK, Panja TK, et al. Infant- and young child-feeding practices in Bankura District, West Bengal, India. J Health Popul Nutr 2010;28(3):294-9.

[11] Joseph N, Unnikrishnan B, Naik VA, et al. Infant rearing practices in South India: a longitudinal study. Journal of Family Medicine and Primary Care 2013;2(1):3743.

[12] Gupta A, Gupta YP. Status of infant and young child feeding in 49 districts of India. BPNI study report 2003: p. 1-25. 